\title{
Evandro de Oliveira, the Rock of Florianopolis
}

\author{
Jacques J. Morcos ${ }^{1,2}$ \\ ${ }^{1}$ Cranial Neurosurgery, Jackson Memorial Hospital, Miami, Florida, \\ United States \\ 2 Professor and Co-Chairman, Director of Cerebrovascular and Skull \\ Base Surgery, Department of Neurosurgery, University of Miami, \\ Florida, USA
}

Arq Bras Neurocir 2021;40(1):14-15.

Why do we exist? How did it all begin? Can we even imagine what nothingness would feel like? Generations of philosophers have pondered these questions and the mystery lingers on. Humans seem equipped with neither the necessary intellect nor imagination to understand their own fate. The inevitability of death, the tragedies of diseases and wars, the pervasiveness of suffering and injustice on this little blue planet, pull us constantly and collectively towards the abyss of despair, the darkness of existential nihilism. Billions are born and billions have died, the cycle continues, and all that Homo sapiens has managed to do, in its quest for meaning and its hunger for relevance, is to celebrate those few men and women among us who break the mold, achieve extraordinary things, and leave an impact. Every breath is precious and every life is sacred, yet some lives well lived simply rise above the rest and inspire the human psyche. Some lives are outliers, are memorable, are infused with such a unique mix of ingredients that they give the rest of us reason to pause, admire and reflect. These lives are the tide that lifts up all struggling boats. These lives are catalysts of human happiness, recipies for human purpose and the very essence of human hope. Most other ordinary lives are but pebbles that leave small ripples in a pond, but these special lives are giant boulders crashing into oceans. They generate an unstoppable wave of influence. On February 11, 2021, one such boulder crashed into the Atlantic Ocean, off the coast of Florianopolis. That boulder had a great life, a life worth celebrating. That rock was called Evandro.

The Evandro tsunami did not start with his death. It had started decades before, when this young gifted Brazilian neurosurgeon became an international beacon for refined microneurosurgical skill, uncompromising love for surgical esthetics, unrivalled passion, unremitting dedication, and unequalled conviction. From the first moment when Evandro stood up behind a lecturing podium, sat down at a dissecting station or braced his arms at the head of an operating table, with his eyes kissing the binoculars of a microscope, the wave started to swell. This rock, this boulder was made of great ingredients: part Yasargil and part Rhoton, yet pure originality. If Rhoton may be thought of as the quintessential neurosurgical "archeologist" who brilliantly uncovered the countless hidden treasures of the brain, Evandro, through skill, predisposition and temperament, is unquestionably the "architect" and "artist" who knew what to do with these treasures. He studied and watched other masters intensely, he refined his art, blazed a trail and founded a massive school of followers. Why did so many follow? After all, he can be dogmatic, uncompromising, even harsh on those less driven, less ambitious. Why? Because his flag is planted in a pure and fertile soil, the soil of undeniable truth and beauty: the structure and mystery of that most complex collection of matter in the universe, the brain. Because to follow him is to follow excellence, courage, the desire to heal and the irresistible impulse to share the wisdom gained along the path. The world would be indeed a much better place if these were its universal motivators, if mediocrity, selfishness and corruptibility were not so pervasive.

Marina, Romina and Sabrina have lost a husband and a father. They have witnessed this giant of a man, this boulder who crushed mountains and moved oceans conclude his earthly life in physical immobility, struck by a disease of the brain, that organ he understood so well. This is cruel and twisted irony, this is poetic injustice. Yet this prophet had done by then all the preaching he needed to do, all the operating he could have accomplished. His masterpieces live on in his writings, his operative videos, his lectures, his patients and his fervent disciples who will undoubtedly now flood the world with their beautiful eulogies. But he
Address for correspondence Jacques J. Morcos, MD, FRCS(Eng),

FRCS(Ed), FAANS, Cranial

DOI https://doi.org/

Neurosurgery, Jackson Memorial

Hospital, Miami, FL, USA

(e-mail: jmorcos@med.miami.edu).
$10.1055 / \mathrm{s}-0041-173027$ ISSN 0103-5355. (c) 2021. Sociedade Brasileira de Neurocirurgia. All rights reserved. This is an open access article published by Thieme under the terms of the Creative Commons Attribution-NonDerivative-NonCommercial-License, permitting copying and reproduction so long as the original work is given appropriate credit. Contents may not be used for commercial purposes, or adapted, remixed, transformed or built upon. (https://creativecommons.org/ licenses/by-nc-nd/4.0/) Thieme Revinter Publicações Ltda., Rua do Matoso 170, Rio de Janeiro, RJ, CEP 20270-135, Brazil 
expects more of them, of all of us. In his last days, you could see it in his eyes. Even when he could not move and could not speak, his mind was talking to us, his neurosurgical peers, and seemed to say:

"If it is not beautiful, it is not true. If you don't do it with pride, with love and with refined knowledge, then don't do it at all. If it is just work for you, then you are missing out on life. If it is not Art, then it is not Science. Please ride the wave, but be bold and be a boulder. Go crash onto other oceans. Carry it forward. You don't have to honor me, but please don't forget what I stood for". I hope I was not the only one listening.

Conflict of Interest

None. 